Parry Sound: Logging Days. John Macfie, The Boston Mills Press, Erin, Ontario, 207 p., 1987, price? ISBN-0-919783-76-7 ( $8 \frac{1}{2}{ }^{\prime \prime} \times 11^{\prime \prime}$ format).

The author recorded on tape between 1962 and 1986 most of the stories recounted in this book. They are first-hand accounts about lumbering as told by lumberjacks, most of whom were born between 1872 and 1898 .

The book is in three parts:

Part 1: Going to the Bush: 14 chapters describe camp life from tree felling to getting the logs to water.

Part 2: Going to the Drive: 12 chapter wherein loggers talk about danger and tragedy, also the skill, cool courage and agility needed to move the logs to the saw mills.

Part 3: Working in the Mill: five chapters about saw-mill operations and related topics such as lumber transportation by trains, ships and educated tram horses.

The text is well supported with excellent photographs of all phases of logging and lumbering and there are 18 pencil sketches illustrating tools of the trade.

This is a story about young men (often mere boys) who 'went to the woods' to become true foresters, skilled in the art of timbering from stump to saw mill. The story tellers relate in detail acquired skills which Chronicle readers will find of special interest. They also tell about escapes from almost certain death, their great love for horses and pride in their profession.

The author has extracted segments from tapes and interviews and inserted them in appropriate parts of the text, e.g., in the chapter entitled 'At work chopping, limbing, loading, skidding' Bill Scott (b. 1887) states "One camp I was in we took out 1900 cords of bark and the logs were just left in the bush. We just cut through them wherever we wanted a trail to get the bark out. We took trees down to the size of stove pipes. On deeded property (being cleared for agriculture) they were logged up, put in great piles and burnt."

Although the book is a factual account of logging in a particular forest area, foresters everywhere will find it informative and entertaining.

An otherwise interesting and adequate glossary refers to a saw's raker teeth as blunted and to a kerf as an uneven part of the end of the log left by the slope of the felling notch. By way of correction raker teeth must be kept sharp to act as chisels in clearing saw dust from the 'kerf' which is the channel made by the saw cut.

Let's hope that the author will someday present to the public other valuable anecdotes which must have been taped during research for this delightful book.

\section{A.G. McDonald}

Sault Ste. Marie, Ontario
Diseases of Trees and Shrubs. Wayne A. Sinclair, Howard H. Lyon and Warren T. Johnson, Comstock Publishing (Cornell Univ. Press), Ithaca, New York, 574 p., US\$49.95, ISBN 0-8014-1517-9.

This book is the best color-illustrated guide to the diseases of trees and shrubs ever produced. Comprehensive and well illustrated, it uses over 1700 color photographs, 8 black and white photographs, and 10 drawings. The latter illustrate specific features observable with a microscope. The photographs appear in plates directly opposite the page containing the descriptive information. There are 350 disease-causing agents described in some detail and many others mentioned briefly. This reviewer was particularly impressed with the inclusion of diseases caused by bacteria, viruses, MLO's and nematodes.

The descriptive information is well done and quite thorough, providing more information than found in any other guide. $A$ reference list with 2284 citations is included, and the text refers to several key papers for each disease covered.

As one would expect with such a large number of photographs, there is room for some improvement. The photographs of Phaeolus schweinitzii are of old sphorophores and several of those pictured for Inonotus tomentosus look like Coltricia cinnamomea. The photographs of the sooty molds could have been better and figure $E$ on Phyllosticta minima resembles the damage caused by the ocellate gall midge Cecidomyia ocellaris. Even with these possible errors, both $I$. tomentosus and $P$. minima are well covered by other photos in their respective plates.

The size of the book makes it unsuitable for field use. The key, while helpful, could have been much better. The lack of information on control and the decision not to use author names for the latin binomials are regrettable.

But in spite of what this reviewer considers as minor shortcomings, the book is better than any other single volume on the subject area. It is to be recommended to any one interested in tree diseases and particularly to foresters and students. Plant pathologists and horticulturists dealing with plant disease identification will find this book very useful, and diagnosticians in plant disease clinics will soon consider it essential in their reference libraries.

\section{D.T. Myren}

Canadian Forestry Service

Sault Ste. Marie, Ontario

Wildlands and Woodlots: The Story of New England's Forests. Lloyd C. Irland, Univ. Press New England, Hanover, N.J., 217 p., 1982, US $\$ 20.00$ cloth 0-87451-2271, US\$9.95 paper 0-87451-351.0.

This book is about New England's (Maine, New Hampshire, Vermont, Massachusetts, Rhode Island and Connecticut) forests, how they have changed since colonial times, and their future importance. It is also an excellent account of life in New England vis-à-vis the region's dominant land use - woodgrowing. Written by a forester for non-foresters, the book is nontechnical.

The author has no reservations about revealing his credentials: "I am an office forester: my lungs have never choked with smoke while fighting a forest fire, nor have my pants ever been spattered with treemarking paint." His view of New England's forest has been acquired "from the office window ...., the university, the bureauracy, official reports, statistics, history books, and talking with colleagues." The data presented in the many figures and tables are mostly estimates. The reader is cautioned about the uncritical use of pre-1950 data; some definitions and mensurational standards of accuracy have changed.

Chapter 1 does well in explaining the importance, historically and economically, of New England's forests. It also sets the stage for the author's ideas and concepts. Chapter 2 deals with the geographical distribution and origins of the forests.

In Chapters 3 through 7, the author has classified the New England forests into five types: industrial, suburban, rural, recreational, and wild. The "Industrial Forest", 13 million acres located primarily in Maine, New Hampshire and Vermont, is operated for industrial wood production. Until the 1850 's the region was largely unexplored. The "Suburban Forest ... is without doubt one of the key amenities contributing to the quality of life" in New England. An increasing portion of the population lives in the suburban forest. Development pressures threaten its survival, Most of the 11million-acre "Rural Forest" is former farmland; farms (most of them abandoned) set the tone of the landscape. This is evidenced in the "old stone walls, forgotten cemeteries ...., and leaf-filled cellarholes." The "Recreational Forest" of 3 million acres, is that set aside principally as a "green backdrop for resorts and second homes."

The author is highly critical of policies governing the management of the recreational forest. Subdivision, non-resident ownership, and scattered development is such that future use of the land for timber, recreation, or any other use is near impossible.

I found the chapter on the "Wild Forest" particularly interesting. In the early 1970's, during my high school years, I travelled many times from southeastern New Brunswick to Squaw Mountain on Moosehead Lake on high school ski trips. The view from I-95 northward to mile-high Mount Kitahdin and the surrounding Baxter State Park area was always awe inspiring. Baxter Park, donated to the state by the late Governor Baxter, remains New England's largest dedicated wilderness area (200 000 acres). The rivers of New England, which have formed the central axis for the regions economic history, mostly have their origins 
in the wild forest. "They have floated logs, powered mills and carried cargoes." The author, in well chosen phrases, extols the beauty of the wildlands and rivers of the "Wild Forest."

The remaining five chapters seem to sum up the author's feelings, philosophies, predictions and hopes for the future of New England's forests. "Forest Land Ownership" explains the structure of forest ownership in New England. The "Timber Budget" (sustained yield/allowable cut) chapter notes how the forest inventories of the 1920 's and '40s predicted shortages that did not materialize. There was no appreciation of growth potential of the forest and the significance of its young age. The chapter on "Wood Products and New England's Economy" reflects what is happening (and predicts what will happen in the future) on a global scale. Demand will increase, and supply (both forest area and timber) will decrease. The author's solution to the problem is commendable - double current growth rates in the commercial forests, maintain the current area of production forest, improve utilization, and increase use of other species. For this to happen "the ecological conscience of all people concerned" must be developed. In the chapter on "Forest Policy" the author advocates a "complete reform of landowner attitudes toward their forests", keeping in mind that three-quarters of $\mathrm{New}$ England's forests are privately owned. The final chapter "The Forest: Past and Future" contains an excellent summary and will interest the reader not only in terms of the New England forest but of forests and forestry worldwide.

The author has made liberal use of tables, figures and charts throughout the text and combining that with exceptional photographs (many of them archival photos from the early 1900 s), the illustrative quality of the book is A-1. The text is clear, well written, and should be completely intelligible to everyone, incluidng "non-foresters." This well researched book (there are 19 pages of bibliographic notes) will be of interest to the general public and foresters alike.

\section{Tom P Weldon}

Canadian Forestry Service

Great Lakes Forestry Centre

Sault Ste. Marie, Ontario

Forest Insects. Principles and Practice of Population Management. A.A. Berryman, Plenum Press, New York, 279 p., 1986, US\$29.50, ISBN 0-306-42196-8.

A number of forest entomology books have appeared on the market during the past decade that concentrate on the insects, but Alan Berryman's book concentrates more on the management of forest insect populations than on the insects themselves. The author assumes that the reader has some understanding of the taxonomy and biology of forest insects. $\mathrm{He}$ then proceeds to discuss control principles. It is not a picture book. Missing are the color plates that adorn books oriented towards identification or the black and whites of the typical university textbook. Figures are almost exclusively graphs (with a scattering of line drawings and rare photo plates). A rare bird indeed. Why would a forester want to get this book? To read!

The book is in four parts. Part I (30 pages) is a well written introduction to the insects and the damages they cause. Part II is ecologically oriented with an excellent chapter on "Insects in the Forest Environment" and chapters on tree defences and the role of insects on forest stability, succession and production. Part III, on management, constitutes the core of the book both in size (40\%) and subject material. This section begins with discussions of monitoring and forecasting. assessing risks, prevention of outbreaks and control. It ends with a most interesting section on evaluating pest management decisions. Part IV, "Practice," contains three case studies that embody the principles discussed earlier in the book.

Several features of this book are worth noting. Each chapter has its own references and a list of selected readings annotated by subject. Since a good text is just a beginning, this feature offers valuable reading. A similar section on a variety of individual insects follows Part IV. Each part concludes with a series of exercises (with answers), making the book more useful as a class text.

On the negative side, I panic a little when I read statements like "Natural selection is probably the best indicator of which species are well adapted to the site. Thus, the selection of species should reflect the natural forest composition." Statements like this are dangerously simplistic if not erroneous and are the inverse of principles found elsewhere in the book. Anyone who has ever found jack pine growing in a swamp as the result of fire pressure and seed source knows that native vegetation is largely a function of local ecological factors and chance.

Otherwise I found this book excellent and would recommend it to practising foresters whose forest entomology course was predominantly insect oriented or who want to improve the effectiveness of their silviculture. It would be very good for use in a college or university course where it could be complemented with lab exercises on forest insect identification and damage.

\section{Tom Eiber}

Insect and Disease Specialist

Minnesota Department of Natural

Resources

Brainerd, Minnesota

Reading Nature's Clues: A Guide to the Wild. Doug Sadler, Broadview Press, Peterborough, Ontario, 245 p., 1987. \$19.95, ISBN 0-921149-15-8.

This is a handsome paperback that I would not want to read from cover to cover but would pick up from time to time to check a few interesting tid bits. Nevertheless it might well be an "eye opener" for neophyte's venture into Nature. Sadler will do this gently: first a description of tire tracks in a drive way, then people's tracks and signs in a park, and finally into the wild to explore Nature's ways. This particular section is juxtaposed with a full page quotation and illustration from a 1904 publication on the expertise of Australian aborigines.

The above example illustrates the approach of an author who, for 30 years, has written an award-winning nature column for the Peterborough Examiner and knows how to pique a layman's interest.

The five chapters and their subdivisions are as follows: 1. Looking at Tracks Some everyday examples; How animals move; Feet features. 2. Habitats and lifestyles - The Forest; Food; Scats (i.e., dung, droppings); Predators; The Earth; Water; Sharing the wealth; Nests, dens and roosts; Scales, shells, and moulting; Hiding and hibernation. 3. Planted Clues - Trees; Winter readiness. 4. Other Signals: Sounds, Smells, Body Language. 5. On the Track of a Whole Continent - Rocks; Ice; The Human Touch. Sources is the title for references that range from the Bible and a 1970 reprint of the 1846 Smith's Canadian Gazeteer to Stewart L. Thomson's Outdoor Rambles of 1958. Most of them were vignettes, framed and allotted a page each. I was sorry that no references were given for the individual subjects discussed. The numerous photographs by the author serve as the only documentation of his theories. An extensive Index is included.

The author has obviously identified with Nature for many years in many different localities. He is both well read and well travelled, as can be seen from the text. Thus we find a photograph of a "Wary Buchell zebra" photographed in Africa juxtaposed with "Algonquin Park white-tailed deer", or the Mexican mountain of Popocatopetl next to the Mount McKay near Thunder Bay, to indicate the parallelism of Nature.

Occasionally some of the botanical detail is inaccurate. For example, I do not believe that a wormy fruit should be regarded as a gall. Nor would I call mushrooms growing on a tree "spore bodies"; these should be properly defined as "spore-bearing bodies".

I think that this book would be a good one to present to the non-professional spouse or teenager. If you do, be ready for some thought-provoking questions.

\section{Erika E. Gaertner}

Economic Botanist, Trenton, Ontario

Forestry and the Forest Industries: Past and Future. E.G. Richards (Ed.), Nijhoff, Dordrecht, The Netherlands for The United Nations, New York, 428 p., 1987. US\$92.50, ISBN 90-247-3592-0. Distributed in Canada and USA by Kluwer 
Academic Publishers, Box 358, Accord Station, Hingham, Massachusetts, 020180358.

The editor's foreword explains that this book is an outcome of decisions taken by the Timber Committee of the United Nations Economic Commission for Europe (ECE) and the European Forestry Commission (EFC) of the Food and Agriculture Organization (FAO) of the United Nations (UN) (OK?) to convene a joint session to discuss the implications of the findings of the FAO/ECE study of European Timber Trends and Prospects to the Year 2000 and Beyond. Each member country was asked to report on: the main problems faced by forestry and forest industries since 1947; the main changes in demand and supply of wood and non-wood goods and services from the forest; the evolution of attitudes towards forestry and forest industries; an assessment of the responsiveness of the sector to change; and the conclusions that can be drawn from all this. Reports were received from 26 countries, including Canada.

In the 17 pages allotted to Canada, a brief but good general overview is given of: Early history; National significance of industry; Regional significance; Industry structure; Trade; The resource; Major products sectors; and Outlook. The overview gives an excellent feel for past and present trends and developments in the industry. The assessed outlook?: "Canada ... with its wood resource base, skilled work force, and competitive production facilities will be in an excellent position to serve [the] growing demand".

Similar national reports are included from: Finland, Norway, Sweden, Denmark, Federal Republic of Germany, the Netherlands, United Kingdom, Austria, Cyprus, Israel, Turkey, Yugoslavia, Bulgaria, German Democratic Republic, Hungary, Poland, and the United States in English; Belgium, France, Italy, Luxembourg, and Switzerland in French with English summaries; Spain in Spanish with English summary; and Czechoslovakia and the Union of Soviet Socialist Republics in Russian with English summaries.- The authors of most of the reports are identified in an appendix, but several reports, including the Canadian, are attributed to "Anon". The disparate authorships must have yielded great variety among the reports. However, it is evident that the editor has been uncommonly successful in welding the various elements (at least those in English) into a well constructed whole.

The book begins with a 28-page overview of the ECE Region (Europe, the USSR, and North America). This section is packed with summarizations of information about world and regional forest land areas, ownership categories, growing stock, forest production, trade, trends, etc.

The value of Forestry and the Forest Industries lies in the ease with which the various parts of the ECE forest industry may be compared (using the best data available) with one another and related to the whole.

\section{R.F. Sutton}

Urban Forestry, 2nd ed. G.W. Grey and Frederick J. Deneke, Wiley, New York, 299 p., 1986, US\$34.95, ISBN 0-471-08813-7.

Like the first edition of Urban Forestry (1978), this book is a good introduction to the topic of managing the municipal tree cover. It provides and overview of urban forestry very valuable to the uninitiated forester who is asked to give advice to a municipality, especially with regard to plantings along streets and roads. The book can also be recommended to members of municipal parks' boards and citizens' advisory committees on environmental matters. It is easily read and well illustrated; however, as one might expect, it does not pretend to be a handbook on the application of forestry principles to the management of municipal forests and parks. Such a book would be far longer.

By deletions and additons, the second edition has been improved over its predecessor. The book's 11 chapters cover the spectrum of municipal forestry. The professional forester may find that the content does not fulfill all his expectations. For example, in chapter 6 (Management of the Urban Forest), which is dedicated to the arboricultural aspects of urban forestry, the statement is made that: "The urban forest has four fundamental needs: planting, maintenance, protection and removal." The use of planting material of the type in general use in forestry, and the need for thinning the resulting plantations are not discussed. These techniques economically could be applied in the development of new parks and certain highway plantings.

Another omission is the lack of information on managing watersheds supplying the urban population with drinking water. The fact that drinking water invariably comes from watersheds, where the tree cover is of the greatest importance for its purity and continuity of flow, appear to have been overlooked in chapter 4 , which otherwise includes all the known benefits of the urban forest.

The new edition has a section on urban wildlife planning, an important improvement over the first edition. Also, a section on the appreciation of urban trees found amongst urbanites has been improved. While new references have been added following each chapter, one weakness of this book is the lack of a complete updating of references to 1986. However, perhaps I am too hard on the authors in this regard.

The success of urban forestry south of the border is such, that if you are not already involved with the giving of advice to municipalities, you may indeed expect a call for this service before long. It is noteworthy, that the "Urban Forestry Working Group" of the Society of American Foresters has grown since 1972 to become the second largest working group (700 members) within the Society. Therefore do not hesitate to educate yourself about urban forestry!

In spite of some deficiencies and the book's leaning toward the area of municipal forestry, I do not hesitate to recommend that you add it to your book collection.

Erik Jorgensen, R.P.F.

Guelph, Ontario

Einwirkungen der Menschen auf die Wälder de borealen kühlen Zonen der Alten Welt: Island, Norwegen, Schweden, Finnland, Sowjetunion. (Effects of human activities on the forests of the temperate boreal zones of the old World: Icleand, Norway, Sweden, Finland, Soviet Union). E.F. Bruenig and J. Poker from a manuscript by L.H. Hesmer (died in 1982), Westdeutscher Verlag, Wiesbaden, $298 \mathrm{p}$., 1986 DM 49. ISBN 3-531-03211-9.

Although much attention has been focused on the distribution of tropical forests and the effects on the environment, the loss of forests in the temperate zones of the world has received relatively little attention. This book concentrates on forest destruction in Iceland, Norway, Sweden, Finland and the Soviet Union. For each of these countries, the geography, topography, soil, climate, population density, and forest conditions are briefly described, followed by more extensive coverage of forest destruction by man, animals, and erosion. These include discussions on the origin and extent of forest fires and the exploitation of forests for naval stores, timber, or pulpwood. While few statistics are given, the authors have included valuable background information that provides the reader with an excellent understanding of the historical sequence of events from the trapping of fur-bearing animals to the introduction of intensive forest management practices. Extensive coverage is given to the forest conditions prevailing in the 20th century. Discussed in detail are forest ownership, inventory of the resource, forest education and research as well as the intensification of various aspects of forest management including planting stock production, fertilization, drainage and the development of specialized forest machinery and implements. More extensive coverage is provided on certain topics, as for example the origins and development of forest education and research in the Soviet Union. Of special interest also are the observations and travel accounts of famous scientists or practising foresters who travelled in these countries and observed forest conditions long before the advent of modern forest management.

The authors provide a wealth of information on all aspects of forestry in all 
five countries covered, and the fluent and easy-to-read style make this book a pleasure to read. This book is highly recommended to anyone interested in the history of forestry and the development of forest management practices in Iceland, Norway, Sweden, Finland or the Soviet Union. Although available only in German, this book should present no great difficulty to anyone with a fair reading knowledge of German.

\section{F.W. von Althen}

Sault Ste. Marie, Ontario

Weeds, 2nd ed. W.C. Muenscher, Cornell University Press, Ithaca, New York, 586 p., 1987 (re-issue of 1955 ed. with new foreword and appendices by P.A. Hypio), US\$16.95, ISBN 0-8014-9417-6 (paperback).

The hardcover edition of Weeds (1980), now selling at US\$39.95, was reviewed in the June 1982 issue of The Forestry Chronicle. The hard- and soft-cover editions are identical in content.

To recapitulate the essence of the earlier review, Weeds would be very useful to foresters working in old fields, but few forest weeds are included. "Agricultural Weeds" would have been a better title. "Within that ambit, the book fully deserves the plaudits that have been bestowed upon it ... In what it sets out to do, Weeds is in a class of its own".

\section{R.F. Sutton}

Wildland Recreation Policy: An Introduction. J. Douglas Wellman, Wiley, New York, 284 p., 1987, US\$29.05, ISBN 0-471-88301-8.

As I embarked on this review, I consulted Bernie Sisam, Emeritus Dean of the Faculty of Forestry, University of Toronto, a keen observer of forestry literature. His first questions were: What is "wildland?"; what is "policy?" The author has attempted, with qualified success, to define or describe the meanings of these terms.

The term wildland, as used here, refers not only to wilderness, but to any lands where the works of nature, rather than those of people, are the main attraction." I consider this a weak definition. For example, fire, which has great influence on forest and many other vegetative environments, is commonly due to the actions of man, although subsequent vegetative development is the work of nature. Nevertheless the definition does suggest a general condition to which most people can relate.

With respect to "policy," Wellman borrows from Heinz Eulan and Kenneth Presitt: "Policy is defined as a standing decision characterized by behavioral consistency and repetitiveness on the part of both those who make it and those who abide by it." On this topic, the author provides some insight into how "issues" are developed and "sold" to the public.
Whether this comes under behavioral consistency or repetitiveness is not at all clear. However, quotations from the book are notable. For example: "... every society ... has its intellectuals sensitive to rationalization of interest and ... preoccupied with the adequacy of opinions about man and nature, equity and justice, and the foundations of government." In this regard, it is worth thinking about another quotation: "As we constantly become more and more nearly lords of creation, there is nothing so much to be feared as ourselves."

The other term in the title "Recreation" is neither defined nor described. Rather it is inferred from the chapter on "The Value of Wildland Recreation in America," in which reference is made to statistics relating to camping, canoeing, hunting, fishing, and hiking. The recreation activities themselves are not a major concern of the author. His orientation is sociological, as indicated by his view of the public need to "come in contact with natural landscapes" and "the benefits of nature should not be restricted to those who can pay for them."

The chapter on "Management: Today's Policy Frontier" was something of a disappointment. This chapter relates to such things as land allocation to conservation and preservational uses and user fees (largely related to varying opinions of the US Congress) for the recreational use of wildland. The closest the author comes to recognizing the importance of the physical manipulation of a site to meet anticipated public demand is indicated by the following: ". . . managers will need to be able to recognize the inevitable limitations of sciences ..." and "Most important is that managers bear in mind that science can only inform decisions, it cannot make them."

This book is written about U.S. forest and conservation institutions, particularly the Forest Service and the National Park Service and about personalities responsible for the development of policy on wildland use in the United States. The latter includes biographical sketches of those who formulated the ideas from which policy was established. These include Gifford Pinchot, John Muir, Aldo Leopold and Robert Marshall. The extensive bibliography is made up almost exclusively of U.S. authors and U.S. publications.

This book was written for a U.S. audience. Those Canadians who realize that many of the issues dealt with in this book have been or will be issues in Canada will find Wellman's presentation well worth reading.

The book should, in my opinion, have been titled "Wildland Policy in the United States."

\section{D.V. Love}

Downsview, Ontario
The 1985 Symposium on Systems Analysis in Forest Resources. P.E. Dress and R.C. Field (Eds.), Georgia Center for Continuing Education, Athens, Georgia, 555 p., 1987, US $\$ 25.00+\$ 5.00$. Available from R.C. Field, 150 Cloverhurst Terrace, Athens, Georgia 30605; make cheques payable to "The 1985 Systems Analysis Proceedings."

These proceedings contain the papers presented at the second symposium on systems analysis in forest resources, held in Athens, Georgia, in 1985, sponsored by the School of Forestry Resources, University of Georgia, USDA Forest Service, Operations Research Society of America, the Institute for Management Science, and the Georgia Center for Continuing Education. University of Georgia.

The proceedings contain 49 articles, divided into ten sections. The first section consists of eight papers dealing with the use of "FORPLAN" in national forest planning. Section two contains seven articles on econometrics, regional analysis, and input-output analysis. Three papers related to dynamic programming make up the third section, while in the fourth section five articles deal with multiple criteria optimization. Optimal control is the subject of the fifth section with three papers, followed by four articles on transportation and engineering. Section seven consists of seven articles on decision support systems and artificial intelligence. Systems dynamics is covered in section eight by three articles while section nine consists of only two papers on risk assessment and pest management. Finally, "other applications of system analysis" are covered in section ten by seven articles.

The variety and quality of papers contained in the proceedings indicate that the operations research professionals have been very active in applying their tools to problems in forest resources management ranging from timber harvest scheduling to multiple use planning and from research planning to graphic simulation of optimal bucking. Although, as might be expected, the technical contents and style of writing vary considerably from article to article, these proceedings as a whole are well written and well organized. Of particular interest is the section on decision support systems and $\mathrm{Al}$ applications in management planning and economic decision making. This is perhaps what will advance rapidly in the near future.

The proceedings represent nearly state of the art in the applications of systems analysis techniques in forestry resource management. The next symposium on this subject is scheduled for March 29, 1988 in the Monterey Peninsula, California. The book is a must for forest econometricians, operations research professionals, and modellers in forest resource management. It could be well used as a reference text for senior and graduate courses in forest econometrics and biometrics.

\section{Bijan Payandeh}

Canadian Forestry Service

Sault Ste. Marie, Ontario 
Immature Insects. Frederick W. Stehr, Kendall/Hunt Publishing, Dubuque, lowa, 754 p., 1987, US\$59.95, ISBN 0-8403-3702-7.

From time to time, books are published that are destined to become classics. Forest entomologists have used one classic (Peterson's 1948 Larvae of Insects) to help identify the insect larval forms that are so important in forestry. After all, no moth or sawfly adult ever caused significant damage to a tree; yet insect taxonomy is based almost exclusively on adult forms. At last, we have a serious, detailed book that deals with these immature forms.

Immature Insects is Volume 1 of a 2volume set that will provide keys for the identification of nymphs and larvae (incomplete and complete metamorphosis) for the Protura, Collembola, Diplura, Microcoryphia, Thysanura, Ephemeroptera, Odonata, Blattodea, Isoptera, Mantodea, Grylloblattodea, Phasmatodea, Orthoptera, Dermaptera, Embiidina, Zoraptera, Plecoptera, Psocoptera, Mallophaga, Anoplura, Mecoptera, Trichoptera, Lepidoptera, and Hymenoptera. The rest of the insects (notably the Hemiptera, Homoptera, Coleoptera and Diptera) will be considered in Volume 2, due in the spring of 1988 .

In the simplest of terms, the book is a classic. It is well illustrated, comprehensive, and contains informative sections on the biology and ecology of the individual families. It will quickly carve out an exclusive niche in those college and university courses dealing with immature insects. It do not recommend this book to the average forester. As an 'identify-thebug-by-the-picture' book, it fails badly and will never replace either the 4-volume series by Rose and Lindquist (Canadian Forestry Service) or Eastern (or Western) Forest Insects (U.S. Forest Service).

This book should have a significant impact in the forest entomological community. It belongs on the bookshelf of every serious pest specialist, but not on the reference shelf at the district level.

\section{Tom Eiber}

Insect and Disease Specialist

Minnesota Department of Natural Resources

Brainerd, Minnesota
Books, not yet to hand for review, of potential interest to members.

The Nature of Wilt Diseases of Plants. C.H. Beckman, APS Press, St. Paul, MN 175 p., 1987, US\$34.00.

Methods for the Diagnosis of Bacterial Diseases of Plants. R.A. Lelliot and D.E. Stead. Published for the British Society for Plant Pathology by Blackwell Scientific, Oxford, 216 p., 1987, US\$26.00 (paper). Methods in Plant Pathology Vol. 2

Pathogenicity of the Pine Wood Nematode. M.J. Wingfield (Ed.), APS Press, St. Paulo, MN, 122 p., 1987, US\$21.00 (paper), based on a symposium, Reno, NV, Aug. 1985

Heartwood and Tree Exudates. W.E. Hillis, Springer-Verlag, New York, NY, 268 p., 1987, US\$89.00. Springer Series in Wood Science.

The Birds of Canada, 2nd ed. W.E. Godfrey, National Museums of Canada, National Museum of Natural Sciences, Ottawa, Ontario, 595 p., 1986

Dictionary of the Physical Sciences: Terms, Formulas, Data. C. Emiliani, Oxford University Press, New York, 379 p., 1987, US\$35.00, ISBN ${ }^{\star * *}-503651-4$ (cloth), US\$19.95, ISBN *** -503652-2 (paper).

Principles of Geographical Information Systems. P.A. Burrough, Oxford University Press, New York, 220 p., 1986, US\$65.00, ISBN ***-854563-0 (cloth), US\$39.95, ISBN ***-854592-4 (paper).

Alcohol and Addictive Behaviour. P.C. Rivers (Ed.), University of Nebraska Press, Lincoln, NE, 346 p., 1987, US\$29.95 (cloth), US\$15.95 (paper). Nebraska Symposium on Motivation, 1986. Current Theory and Research in Motivation, Vol. 34

Hazardous Chemicals Desk Reference. N.I. Sax and R.J. Lewis, Van Nostrand Reinhold, New York, 1084 p., 1987. US\$69.95

Hazardous Materials Storage and Handling Handbook. 98 p., 1987 , US $\$ 9.50+25 \%$, Superintendent of Documents, U.S. Government Printing Office, Dept. 33, Washington, D.C. 20402, Cat. No. S/N 008-007-03281-0.

National Trends in Drug Use and Related Factors Among American High School Students and Young Adults, 1975-1986. 279 p., 1987, US $\$ 8.50+25 \%$, Superintendent of Documents, U.S Government Printing Office, Dept. 33, Washington, D.C. 20402, Cat. No. HE 20.8102:Am 3, S/N 017-024-01332-3.
Inquest on the Shroud of Turin, 2nd ed. J. Nickell, Prometheus, Buffalo, NY, 186 p. 1987, US\$12.95 (paper).

Taxation and Savings in Canada. C.M Beach, R.W. Boadway, and N. Bruce. A study prepared for the Economic Counci of Canada. Canadian Government Publishing Centre, Ottawa, Ontario K1A 0S9 C. 350 p., 1987, \$10.95 in Canada, \$13.15 elsewhere, ISBN 0-660-12552-8, Cat. No. EC22-144-1987E. Aussi disponible en français sous le titre: La fiscalité et l'épargne au Canada, Cat. No. EC22-1441987F.

The Taxation of Savings and Investment. A research report prepared for the Economic Council of Canada. Canadian Government Publishing Centre, Ottawa, Ontario K1A 0S9, c. 350 p., 1987, $\$ 10.95$ in Canada, \$13.15 elsewhere, ISBN 0-66012532-3 (paper), Cat. No. EC22-1431987E. Aussi disponible en français sous le titre: Une réforme de l'impôt sur l'épargne et l'investissement, Cat. No. EC22-143-1987F.

Workplace Innovation in Canada. J. Mansell. Economic Council of Canada. Canadian Government Publishing Centre, Ottawa, Ontario K1A 0S9, ? p., 1987, \$4.95 in Canada, $\$ 5.95$ elsewhere, ISBN 0-66012554-4 (? paper), Cat. No. EC22-1461987E. Aussi disponible en français sous le titre: L'innovation en milieu de travail au Canada, Cat. No. EC22-146-1987F.

Job Futures: An Occupational Outlook to 1995, 1988-1989 Edition. Canadian Government Publishing Centre, Ottawa, Ontario K1A 0S9, ? p., 1988, \$9.95 in Canada, add $20 \%$ elsewhere, ISBN 0-66012614-1 (paper, 2-vol. set), Cat. No. MP43-181/1989-1E; ISBN 0-660-126176 (looseleaf), Cat. MP43-181/1989-2E. Aussi disponible en français sous le titre: Emploi-avenir: perspectives professionnelles jusqu'à 1995. ISBN 0-660-92172-3 (Jeu de 2 vol. reliés), Cat. No. MP43-181/ 1989-1F; ISBN 0-660-92175-8 (Feuillesmobiles), Cat. MP43-181/1989-2F. An electronic version ("no discounts/no returns; pas de remise/pas de retour"), in either English or French, is available for $\$ 200.00$.

Jobs for the Future. 84 p., 1987, US $\$ 4.00$ $+25 \%$, Superintendent of Documents, U.S. Government Printing Office, Dept. 33, Washington, D.C. 20402, Cat. No. S/N 029-002-0075-4.

Guide for the Selection and Use of Microcomputers. 69 p., 1987, US $\$ 4.00+$ $25 \%$, Superintendent of Documents, U.S. Government Printing Office, Dept. 33, Washington, D.C. 20402, Cat. No. S/N 022-003-01141-2 